\title{
Preservation of Beta Cell Function in Adult Human Pancreatic Islets for Several Months in Vitro
}

\author{
J. H. Nielsen, J. Brunstedt, A. Andersson ${ }^{1}$, and C. Frimodt-Møller ${ }^{2}$ \\ Steno Memorial Hospital, Research Laboratory, Gentofte, Denmark, ${ }^{1}$ Department of Histology, University of Uppsala, Uppsala, Sweden, \\ and ${ }^{2}$ Department of Surgery, Rigshospitalet, University of Copenhagen, Copenhagen, Denmark
}

\begin{abstract}
Summary. Islets of Langerhans were isolated from four human kidney donors, aged 16 to 21 years, by the collagenase method described for isolation of rodent islets. So far the human islets have been kept in tissue culture, without attachment, in medium RPMI 1640 supplemented with $10 \%$ calf serum for more than 9 months, with preservation of the ability to release insulin in response to glucose stimulation. Replacement of calf serum with serum from normal human subjects did not affect B-cell survival, but resulted in elevated insulin values partly due to lower insulin degrading activity. Thus the described technique presents a valuable tool for studying chronic effects of metabolites and hormones on islet function, as well as for islet storage prior to transplantation into humans.
\end{abstract}

Key words: Human pancreatic islets, tissue culture, beta cell function, islet storage.

Long-term preservation of hormone producing cells in vitro is important for several reasons, including storage of cells intended for eventual transplantation, and development of in vitro systems for hormone production. So far it has been possible in only a few cases to maintain hormone production of endocrine cells in culture for more than a few weeks [16]. The most extensively studied systems have been established cell lines developed from a rat pituitary tumour [7]. Several attempts to culture endocrine pancreatic tissue as explants, monolayers, or isolated islets of Langerhans have been undertaken [1], but in most cases insulin secretion declined to very low values after some weeks in culture. Most promising, with respect to the preservation of beta-cell function, seems to be the culture of isolated islets.
Isolation of islets from adult human pancreas involves certain difficulties [13], but in a recent study a sufficient number of islets was obtained from 9 out of 14 glands and their morphology and specific functions were maintained for 1 to 3 weeks in culture [3].

We report here experiments with long-term maintenance of isolated human islets using a modified culture technique.

\section{Materials and Methods}

Human islets were isolated by essentially the same technique as described for rodent islets [4].

Pancreatic tissue from four human kidney donors, aged 16 to 21 years, was processed within 1 to $2 \mathrm{~h}$ of circulatory arrest. Consent was obtained from the patients' relatives prior to the removal of the organ. Following 15-20 min of warm ischaemia the caudal part of the pancreas was transported to the laboratory in isotonic saline $(154 \mathrm{mmol} / 1 \mathrm{NaCl})$ at $4{ }^{\circ} \mathrm{C}$ and 50 to $100 \mathrm{mg}$ tissue was cut into small pieces with a pair of iris scissors and washed several times with Hanks' balanced salt solution (Flow) supplemented with $25 \mathrm{mmol} / 1$ HEPES and adjusted to $\mathrm{pH} 7.4$ (HBSS). The minced tissue was transferred to a sterile tube with $15-20 \mathrm{mg}$ collagenase (Sigma type I) in approximately $2 \mathrm{ml}$ HBSS and shaken by hand for about $25 \mathrm{~min}$. When free islets were seen under the microscope, the tissue was allowed to settle and was washed several times with HBSS. Islets were then picked up with a braking pipette from a Petri dish under 10-20 times magnification. Some exocrine tissue was attached to the islets and much of the tissue was adherent to fibrous threads, but in each case 100 to 200 isolated islets were obtained and transferred to plastic Petri dishes (Nunc) to which the islets do not attach and the cultures were incubated at $37{ }^{\circ} \mathrm{C}$ in a humidified atmosphere of $95 \%$ air and $5 \%$ $\mathrm{CO}_{2}$. In each dish 20 to 50 islets were placed in $5 \mathrm{ml}$ of culture medium consisting of RPMI 1640 (Flow) supplemented with $10000 \mathrm{U} / 1$ penicillin, $100 \mathrm{mg} / 1$ streptomycin and $10 \%$ newborn calf serum (NCS, Gibco). The glucose concentration was $2 \mathrm{mg} / \mathrm{ml}$ $(11 \mathrm{mmol} / \mathrm{l})$. The medium was changed twice per week.

In one case the calf serum was replaced with a human serum pool obtained from 10 healthy volunteers. The serum pool was sterile filtered and stored at $20^{\circ} \mathrm{C}$.

In order to study the insulin response to glucose, islets were transferred from the culture medium to medium 199 without glucose (Flow) supplemented with $2 \mathrm{~g} / 1$ human serum albumin 


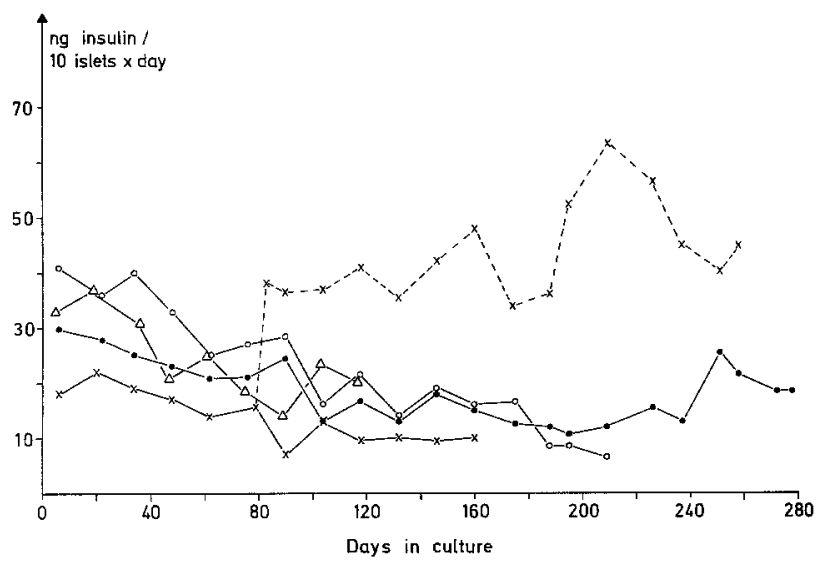

Fig. 1. Insulin release from human islets cultured in medium RPMI 1640 supplemented with $10 \%$ newborn calf serum (or $10 \%$ normal human serum $(-----)$. The figure shows the insulin content in the medium in the 4 cases: $A(\bullet), B(\times), C(O)$, and $D(\Delta)$. Each point represents the mean content of media from 1 to 5 dishes with 20 to 50 islets in each

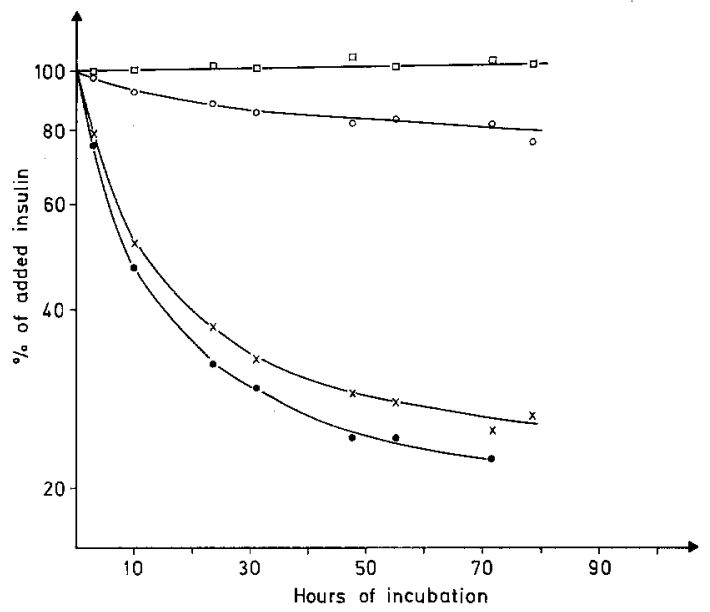

Fig. 2. Degradation of insulin in RPMI 1640 containing $10 \%$ newborn calf serum $(\bullet)$, fetal calf serum $(\times)$, fetal calf serum, heat inactivated $(O)$ and human serum $(\square)$. The initial concentration of insulin was $200 \mathrm{ng} / \mathrm{ml}$

(Behringwerke) for $30 \mathrm{~min}$ before the secretion experiments. In these islets were exposed consecutively for $30 \mathrm{~min}$ periods to the same medium with 0,10 and $20 \mathrm{mmol} / 1$ glucose and $20 \mathrm{mmol} / 1$ glucose plus $5 \mathrm{mmol} / 1$ theophylline. Insulin was determined by radioimmunoassay using porcine insulin (Nordisk Insulinlaboratorium) as standard.

The degradation of insulin in the culture medium was elucidated by adding insulin and a tracer amount of ${ }^{125} \mathrm{I}$-insulin (final specific radioactivity $2 \mu \mathrm{Ci} / \mu \mathrm{g}$ insulin) to medium RPMI 1640 supplemented with $10 \%$ newborn calf serum (Gibco), fetal calf serum (Flow), fetal calf serum heat inactivated at $56^{\circ} \mathrm{C}$ for $30 \mathrm{~min}$, or a normal human serum pool. Samples were taken at different periods during incubation at $37^{\circ} \mathrm{C}$, and the degradation was obtained from the percentage of the radioactivity which bound to insulin anti-serum and precipitated with $12 \% \mathrm{w} / \mathrm{v}$ polyethylene glycol (PEG 6000).

\section{Results}

The release of insulin into the culture medium from the 4 human islet preparations is shown in Figure 1. Except for a high rate of secretion during the first days of culture the release of insulin into the medium only decreased slightly during the subsequent 2 to 40 weeks. Replacement of calf serum by normal human serum is seen to cause a drastic increase of the insulin content of the culture medium. As shown in Figure 2 insulin was rapidly degraded in the culture medium containing non-heat inactivated calf serum. Heat inactivation prevented most of the degrading activity and with human serum the degradation was almost negligible. The apparent increase during the incubation was due to evaporation amounting to about $10 \%$ in 3 days.

Short-term exposure of the islets to $20 \mathrm{mM}$ glucose plus $5 \mathrm{mM}$ theophylline and in some cases also to 0,10 and $20 \mathrm{mmol} / 1$ glucose without theophylline after different culture periods gave the results shown in Figure 3. The insulin responsiveness to both glucose alone and glucose with theophylline was maintained in each group of human islets during the actual observation period, although differences existed between islets isolated from the 4 different donors. A certain decrease is apparent, but in all cases the maximal insulin release was 3 to 10 times higher than the rate of secretion in the absence of glucose and theophylline.

\section{Discussion}

The present results demonstrate that it is possible to maintain adult human islets of Langerhans for a considerable length of time with little change in insulin production and maintenance of a normal response to glucose.

Others have reported preservation of islets from mice and rats for up to 75 [14] or 97 days [15], but the ability of the islets to respond to glucose gradually diminished.

By keeping islets from human fetuses floating, a better preservation of the insulin production was found after 2 months and in some cases insulin could be detected for up to 80 days [8]. Obviously, the glucose concentration of the culture medium is an important factor for maintaining the endocrine function of the islet tissue $[4,6,10,17]$, but other constituents of the medium are also of significance. Among different commercially available media, RPMI 1640, which contains $11 \mathrm{mmol} / \mathrm{l}$ glucose, was found to be superior with respect to the response to glucose of mouse islets after one week in free floating 


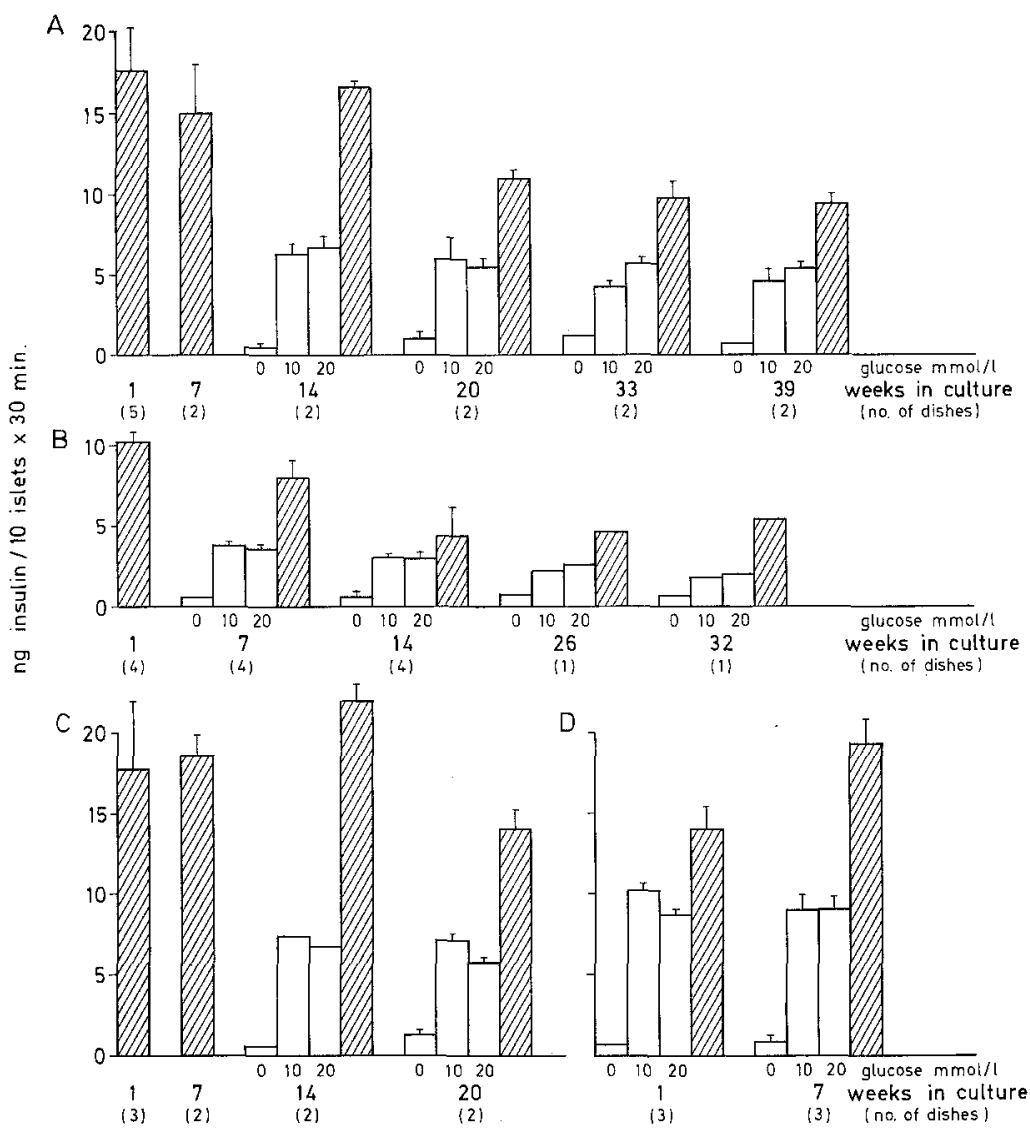

Fig. 3. Glucose induced insulin release from human islets cultured for different time periods in medium RPMI 1640 supplemented with $10 \%$ newborn calf serum. The islets were in all cases exposed to

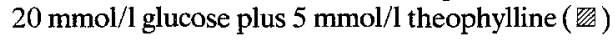
and in some cases also for preceding 30 minute periods to 0,10 and $20 \mathrm{mmol} / 1$ glucose $(\square)$ added to medium 199 with $2 \mathrm{~g} / \mathrm{l}$ albumin. The culture periods are given in weeks. The 4 cases A, B, C, and $D$ correspond to those shown in fig. 1 . The results are given as mean \pm SEM of 1 to 5 dishes. In case $B$ the results of week 26 and 32 are from islets cultured in human serum culture [2]. Under similar conditions mouse islets could be maintained for one year (data not shown) and for more than 5 months when the proper $\mathrm{pH}$ 7.2 - of the culture medium was maintained with HEPES-buffer without supplying carbon dioxide to the gaseous phase [5].

The present study shows that adult human islets can also be maintained for several months by using RPMI 1640 and Petri dishes which do not permit attachment of the islets. The isolation procedure was presumably facilitated by the youth, 16 to 21 years, of the donors [3]. The increased insulin concentration in the medium observed when calf serum was replaced with normal human serum is probably due to the low insulin degrading capacity of human serum as compared to that of non-heat inactivated calf serum [9]. Taking these findings into consideration it is obvious that the figures for the insulin accumulation in the calf serum supplemented culture medium are all underestimates.

The release of human C-peptide during culture was, in preliminary measurements, approximately equimolar with insulin in the media containing calf serum; it was somewhat lower in the medium containing human serum (to be published). However, differences in degradation of insulin and C-peptide in the media as well as the contribution from proinsulin have to be considered.

It cannot be ruled out that human serum in addition may contain insulinotrophic factors, as demonstrated in serum from diabetic patients under similar experimental conditions [12]. The fluctuations in insulin release may be due to differences in batches of media. Termination of cultures was always due to microbial contamination of the media.

While the response to glucose plus theophylline showed some variability, the response to glucose alone was fairly constant within islets from the same individual. Whether the individual difference reflects a methodological variability or a clinical feature cannot be said. It may be noted that none of the donors had both HLA-types B8 and BW15, which have been shown to be associated with juvenile diabetes mellitus [11].

In conclusion, the present results indicate that it is possible to maintain human islets of Langerhans in vitro with the present simple culture system for up to 9 months, or even longer, with an intact insulin production. This technique should prove valuable for studying chronic effects of hormones and metabolites 
on islet function and eventually islet storage for human transplantation.

Acknowledgements. We thank Mrs. Kirsten Brunstedt, Mrs. Dagny Jensen, and Miss Ragna Jørgensen for expert technical assistance.

\section{References}

1. Andersson, A.: Tissue culture of isolated pancreatic islets. Acta Endocrinol. [Suppl.] (Kbh.) 205, 283-293 (1976)

2. Andersson, A.: Isolated mouse pancreatic islet in culture: Effects of serum and different culture media on the insulin production of the islets. Diabetologia 14, 397-404 (1978)

3. Andersson, A., Borg, H., Groth, C. G., Gunnarsson, R., Hellerström, C., Lundgren, G., Westman, J., Ostman, J.: Survival of isolated human islets of Langerhans maintained in tissue culture. J. Clin. Invest. 57, 1295-1301 (1976)

4. Andersson, A., Hellerström, C.: Metabolic characteristics of isolated pancreatic islets in tissue culture. Diabetes 21 [Suppl. 2], 546-554 (1972)

5. Brunstedt, J., Nielsen, J. H.: Long-term effect of $\mathrm{pH}$ on B-cell function in isolated islets of Langerhans in tissue culture. Diabetologia 15, 181-185 (1978)

6. Buitrago, A., Gylfe, E., Hellman, B., Idahl, L.-Å., Johansson, M.: Function of microdissected islets cultured in a chemically defined medium. I. Insulin content and release. Diabetologia 11, 535-540 (1975)

7. Dannies, P. S., Tashjian, A. H., Jr.: Growth hormone and prolactin from rat pituitary tumor cells. In: Tissue culture, methods and applications. Kruse, P. F., Jr., Patterson, M. K., Jr. (eds.), pp. 561-569. New York: Academic Press 1973

8. Goldman, H., Colle, E.: Human pancreatic islets in culture. Effects of supplementing the medium with homologous and heterologous serum. Science 192, 1014-1016 (1976)

9. Kedinger, M., Moody, A., Lanny, J. F., Haffer, K.: Establishment of serum based medium essentially free of proteolytic activity for the culture of mouse pancreatic islets. Experientia 33, 972-973 (1977)

10. Lacy, P. E., Finke, E. H., Gonant, S., Naber, S.: Long-term perifusion of isolated rat islets in vitro. Diabetes 25, 484-493 (1976)

11. Nerup, J., Platz, P., Andersen, O. O., Christy, M., Lyngsøe, J., Poulsen, J. E., Ryder, L. P., Nielsen, L. S., Thomsen, M., Svejgaard, A.: HL-A antigens and diabetes mellitus. Lancet 1974 II, 864-866

12. Nielsen, J. H., Eff, C., Deckert, T., Jensen, D., Brunstedt, K., Andersson, A.: Effect of diabetic sera on isolated islets in tissue culture. Diabetologia 13, 421 (1977)

13. Sutherland, D. E. R., Steffes, M. W., Baner, G. E., McManus, D., Noe, B., Najarian, J. S.: Isolation of human and porcine islets of Langerhans and islet transplantation in pigs. J. Surg. Res. 16, 102-111 (1974)

14. Takaki, R., Ono, J., Fukuma, M., Ikegami, T.: Long-term culture of isolated pancreatic islet cells. Proc. Soc. Exp. Biol. Med. 149, 402-406 (1975)

15. Tze, W. J., Chen, L. M.: Long-term survival of adult rat islets of Langerhans in artificial capillary culture units. Diabetes 26, 185-191 (1977)

16. Wighley, C. B.: Differentiated cells in vitro. Differentiation 4, 25-55 (1975)

17. Ziegler, B., Hahn, H.-J., Speck, G. A., Ziegler, M.: Untersuchen an Langerhansschen Inseln in vitro. XI: Insulinsekretion und Insulingehalt Isolierter Langerhansscher Inseln der Wistar-Ratte in Kurzzeitinkubation und unter Organkulturbedingungen. Endokrinologie 64, 269-276 (1975)

Received: July 13, 1978, and in revised form: September 12, 1978

Dr. J. Høiriis Nielsen

Steno Memorial Hospital

Research Laboratory

Niels Steensensvej 6

DK-2820 Gentofte, Denmark 